Feren Alia Hidayat ${ }^{1}$, Moses Glorino Rumambo Pandin ${ }^{2}$

${ }^{1}$ Faculty of Psychology, ${ }^{2}$ Faculty of Humanities,

Airlangga University Surabaya, Indonesia

Airlangga street No. 4-6, Airlangga, Gubeng District, Surabaya City, East Java 60115

feren.alia.hidayat-2020@psikologi.unair.ac.id; moses.glorino@ fib.unair.ac.id

\title{
BOOK REVIEW: \\ LANGKAH MEMBANGKITKAN GENERASI MUDA YANG BERBUDAYA: MENGENAL BUDAYA INDONESIA, UPAYA MELESTARIKAN BUDAYA INDONESIA, CARA GAUL MILLENIAL BERBUDAYA DAN PERAN BAHASA DALAM KOMUNIKASI AANTAR BUDAYA
}

\section{(WAYS TO IMPROVE THE YOUNG GENERATIONS CULTURE: GET TO KNOW INDONESIAN CULTURE, AN EFFORTS TO PRESERVE INDONESIAN CCULTURE, HOW MILLENIAL GETTING ALONG, AND THE ROLE OF LANGUAGE IN INTERCULTURAL COMMUNICATION)}

Book Title: Langkah Membangkitkan Generasi Muda yang Berbudaya: Mengenal Budaya indonesia, Upaya Melestarikan Budaya Indonesia, Cara Gaul Millenial Berbudaya dan Peran Bahasa dalam Komunikasi Antar Budaya (Ways to Improve the Young Generations Culture: Get to Know Indonesian Culture, an Efforts to Preserve Indonesian Culture, How Millennial Getting Along, and the Role of Language in Intercultural Communication); Author: Siti Nur Aidah; Publisher: KBM Indonesia; City: Bojonegoro, East Java, Indonesia; Edition: First edition, 2020; Pages: 71 pages; Book size: 14 x 21 cm; ISBN: 978-623-6965-07-8

\section{INTRODUCTION}

Indonesia has a variety of cultural diversity spread in each province. However, as time goes by, Indonesian culture has begun to be displaced. Indonesians, especially the younger generations, are beginning to abandon the local culture. They prefer more on Western culture, which they found as modern ones and adopt their lifestyle without even filtering it. As a result, Indonesia has their character identity. Other countries have repeatedly claimed some Indonesian heritage because of its people habits that don't care about their culture. Therefore, it is important to build a cultural character for the young generations to reflect, loves and cherishes their culture.

Ways to Improve the Young Generations Culture was written for Indonesian people, especially the young generations who have forgotten about their culture. Hopefully, it will help the young generations realize how much they have abandoned their own culture and how their preferred foreign cultures are unsuitable. Ways to Improve the Young Generations Culture reintroduced Indonesian culture from each region to remind millennials about that the identity of the Indonesian nation has begun to drift away was also explained. Aside from that, there are 
solutions and tips to preserve and introduce Indonesian culture to the international market. It contains various new information widely unknown by the young generation, such as cultural awareness, the theory of cultural synchronization, cultural confrontation, cultural experience, cultural knowledge, and how millennials preserve their culture. With that being said, it will be undoubtedly helpful for the readers' lives that persuade them to care more about their society and their culture. The evidence presented was pretty convincing because, in reality, the young generations does consider Indonesian culture outdated. They even tend to boast about Western culture more than Indonesian culture. It discusses an interesting and relevant theme; hence, people are attracted to this Siti Nur Aidah's work. As Indonesians, especially the young generations who holds the key to taking care of our culture, we should read this book as it plays an important part in improving the character of the young generations so Indonesian culture will continue to rise instead of facing extinction due to globalization.

This review aims to fulfil the final project of the Pancasila course. In addition, this review was also made to provide a comprehensive understanding of the content in Ways to Improve the Young Generations Culture: Get to Know Indonesian Culture, an Efforts to Preserve Indonesian Culture, How Millennial Getting Along, and the Role of Language in Intercultural Communication to the readers based on the perspective of the reviewer. With this review, the reviewer hopes that the young generations can utilize this review as an afterthought and self-reflection in order to love Indonesian culture more. Last, this review also aims to give the readers consideration about the strengths and weaknesses of the book.

\section{REVIEW}

Siti Nur Aidah wrote Ways to Improve the Young Generations Culture to the identity of the Indonesian nation beginning to fade away. As time goes by, Indonesian culture is slowly being put aside, causing many other foreign cultures can easily blend in with Indonesian culture. The entrance of these foreign cultures affecting young generations to abandon their own culture, and assimilation occurred. Millennials were unable to filter which culture is good and bad, so they are easily carried away by foreign cultures contrary to the Indonesian culture. For example, the way Westerners dress openly contradict the local manners in Indonesia. But the young generations prefers the Western culture because it is considered trendier than the "outdated" local culture and make them neglect their own culture.

The young generations is the country's hope to preserving national culture, but reality says otherwise; they are the ones who begin to neglect it. Various factors cause millennials to prefer Western culture, one of them being the practicality and modernity of the culture. It also 
becomes a lot easier in this globalization era for Western civilization to enter through mass media. The role of the entire nation is needed to preserve Indonesian culture and young generations character. Several things can be carried out to raise cultural awareness: instilling an attitude of multiculturalism since childhood, socializing Indonesian culture through academic institutions, organizing various art performances containing local culture, introducing Indonesian culture through local arts since childhood, being selective in filtering foreign cultures according to Indonesian culture, and loving and preserving our own culture. In this digital age, using social media to promote and spread our culture is one tricks that can be used.

Culture is a tradition that contains values passed down from generation to generation to be explored, studied, and preserved by the next generation. Indonesia has various cultures that show the characteristics and uniqueness of each region, namely traditional clothes, traditional houses, songs, dances, and musical instruments. Indonesian culture has changed periodically due to globalization. In this era of globalization, information has a tremendous power to influence people's mindset. Western culture is recognized as a culture that has gone through modernization. Meanwhile, eastern culture is known as traditional and conventional culture. Society does not merely absorb western science and technology but also blindly imitates the whole pattern of the western lifestyle. It is unfortunate, considering Indonesia itself is a country that possesses various unique and beautiful cultures that make tourists very enthusiastic to witness various local Indonesian cultures.

Satellite countries, especially the United States, have a lifestyle imitated by other metropolis countries, causing all local cultures to experience chaos, even on the verge of extinction. Such assimilation will result in the loss of a passive and weak culture. Sadly, this phenomenon happens to Indonesian people who prefer a "more modern" culture, Western culture. These days, the people outside of Indonesia know better about and are more intrigued by Indonesian culture than Indonesians themselves. Therefore, Indonesia is more enthusiastic and eager about promoting its culture internationally. As an example, batik is one of the cultures that highly interests non-Indonesians and has been designated by UNESCO as a cultural heritage of Indonesia.

Indonesian culture will not develop without the role of young people. It is in line with the fact that young generations began to abandon their own culture and follow various kinds of foreign cultures without filtering it. The lack of cultural learning is one of the reasons why local culture is starting to fade away. These days, learning about culture is considered unimportant, when in fact, cultural learning can help develop national culture and adapt local 
culture in this era of globalization. There are several ways that people can preserve and maintain local culture, namely by cultural experience and cultural knowledge. Cultural experience is one of the many ways to preserving culture by directly contributing to a cultural experience. Meanwhile, cultural knowledge is another way of cultural preservation by creating an information center about a culture that can be implemented in various forms. In addition, there are also other ways to preserve local culture, namely by maximizing the quality of human resources to develop local culture, encouraging people to optimize the potential of local culture, raising awareness of the potential of local culture and its preservation, building high solidarity, kinship, tolerance, and more intense hospitality, early cultural learning, and providing art learning based on local culture to form the character of Indonesia's young generations who appreciates their own culture.

Culture is often identified as something beautiful, such as fine art, dance, philosophy, temples, songs, and literature. Koentjaraningrat (2004) inferred that culture has three forms, namely: A. as a complex of ideas, values, norms, regulations, etc. B. as a complex activity of patterned behaviour of human beings in society. C. as objects of human works. Wunderle mentioned several levels of cultural awareness: A. data and information. B. culture consideration. C. culture knowledge, and D. culture competence. There are several ways to create a soul that loves local culture, namely: instilling an attitude of multiculturalism since childhood, socializing Indonesian culture through academic institutions, organizing various art performances containing local culture, and loving and preserving one's own culture.

There are various reasons why the younger generations does not genuinely care about Indonesian culture, namely: the curriculum of elementary school, junior high school, and high school are more concerned with achievements in the academic field, the school curriculum teaches more about theory than practice, parents do not teach much about cultural arts to children, and various electronic mass media show more entertainment programs that lead to foreign cultures.

Indonesian culture can be maintained and preserved by the community through the implementation of education. Firstly, through a formal way by establishing a society that has notable integration or integrity. This can be achieved by applying multicultural education and establishing a symbiotic relationship of mutualism between people. In addition to the formal way, the implementation of education can also be executed through informal means achieved by approaching the younger generations to Indonesian traditions.

There are various ways for millennials to maintain the sustainability of Indonesian art and culture, starting from building a character that loves Indonesian art, creating a community 
engaged in the field of Indonesian art and culture, interestingly exploring Indonesian art, reducing the consumption of art from foreign nations, and functionalizing technology and the internet as a medium to promote Indonesian art.

Indonesia is a country that has a variety of cultures; thus, intercultural communication is frequently experienced. Intercultural communication occurs when there is communication between individuals with different cultures to achieve the same communication purposes. Intercultural communication also encourages smooth interaction. Intercultural communication itself has the purpose of expressing social identity, expressing social interaction, increasing knowledge, creating complementary relationships that are aligned, reducing uncertainty, and encouraging the reconciliation of the people fighting due to misunderstandings. What motivates intercultural communication to occur are mobility, economy, technology, immigration, and politics. Intercultural communication can be done using the national language, Bahasa Indonesia, to prevent misunderstandings. Many people consider intercultural communication has a similar meaning with cross-cultural communication, when in reality, cross-cultural communication focuses on the differences in interpersonal communication activities in their respective cultures. On the other hand, intercultural communication is communication between two individuals with different lifestyles.

This book was written due to the increasing number of young people who have forgotten about their own culture. They prefer the Western culture because it is considered trendier than the "outdated" local culture. Ways to Improve the Young Generations Culture was written for Indonesian people, especially the young generations who have forgotten about Indonesian culture. Hopefully, the young generations can realize how much they have abandoned their own culture and how their preferred foreign cultures are not all suitable for them. The content of the book can remind millennials that the identity of the Indonesian nation has begun to drift away because it reintroduced Indonesian culture from each region. It will encourage the young generations to love Indonesian culture and remind them of preserving it. There are also solutions and tips on how millennials can keep Indonesian culture and introduce it to the international market. The writer wants to inform the readers on how vital intercultural communication is to prevent misunderstandings. It is also essential for parents and academic institutions to know how important it is for children to love Indonesian culture early on and provide cultural lessons in schools.

This book contains recent information widely unknown by the young generations, such as cultural awareness, the theory of cultural synchronization, cultural confrontation, cultural experience, cultural knowledge, and the way millennials preserve culture. There is also an 
explanation of how the school curriculum does not support cultural preservation. Such information will certainly be practical in the daily life of the readers, especially the young generations. They will become proud of their culture, even to the point of showing it off to the whole world. However, if academic institutions and parents read Ways to Improve the Young Generations Culture, they will comprehend how their encouragement is not enough to make the young generations love their culture.

The evidence presented was pretty convincing because, in reality, the young generations indeed consider Indonesian culture as outdated. They even tend to boast about Western culture more than Indonesian culture. They are more familiar with Western songs and dances. They prefer celebrating birthdays in restaurants that serve Western food rather than local food. Even Indonesian television stations prefer showing foreign movies despite containing violence and sex. Other evidences presented in the book comes from journals and quotes of well-known figures, such as researcher and education consultant Doni Koesoema, J.J Hoenigman, sociologist Talcott Parsons, anthropologist A. L. Kroeber, Wunderle, and many more.

The style of the book fits the theme presented. The red color from the cover could mean courage, strength, and passion. It also represents the power of the young generations. The content of this book is easy to understand because it does not use too much complex diction. The organization and structure of the book are appropriately made. The author begins the book by introducing Indonesian culture, how Indonesian culture is starting to drift away, and preserving Indonesian culture. However, the last part of the book discusses intercultural communication and the role of language that does not fit with the previous topics. The size of the book is $14 \times 21 \mathrm{~cm}$ or A5, the standardized paper size for the majority of the books in Indonesia.

The author of the book has also presented ideas, facts, and studies, such as how Indonesian culture has been recognized by UNESCO, various cultures that develop in Indonesia, culture and culture awareness, factors that cause the weakening of Indonesian culture, solutions to help improve the character of the young generations to love their culture, the functions and purposes of intercultural communication, the role of language in intercultural communication, and many more. There are no studies, facts, and ideas that the author has neglected to consider. The lack of parental and academic institutional roles is unignored by the author either.

The reviewer's advice for this book is that the book's author can improve their writing to make it neater and matches what has been determined in Indonesian Spelling System General 
Guidelines (EYD). The discussion can also be made more detailed and broader to cover more material. An addition of conclusions can be considered to make it easier for the readers to understand and summarize the book's contents.

This book discusses an interesting and relevant theme; hence, people are tempted to read this Siti Nur Aidah's work. It also has an important part in improving the character of Indonesia's young generations so Indonesian culture will not be harmed due to globalization. Indonesians will know the state of Indonesian culture on the verge of extinction. The subject raised by the author can make Indonesians put more effort into preserving Indonesian culture and realize just how beautiful Indonesian culture is, even when compared with Western culture.

This book has a relatively new year of publication, which can serve as an advantage since it means the book's content is more relevant in today's life. From the problems discussed to the solutions provided, it can be felt and implemented by the readers. It has another strength, for instance the interesting cover of the book that attracts the readers. The red colour of the cover makes the book more eye-catching. The book's design is appealing as well, with people raising one hand and their facial expressions demonstrating a burning spirit, depicting the struggles of the late heroes. In addition, there are also pictures of Indonesian cultures such as people dancing traditional dances. The pictures in the book, too, make the readers maintain a constant interest, compared to only reading words. The language used by the author is also easy to understand.

Besides its strengths, there are some drawbacks to this book. Many discussions are repeated frequently to the point that it seems that the contents of the book are only circling. The writing does not match Indonesian Spelling System General Guidelines (EYD), some spaces that should be included between different words are excluded, many sentences are ineffective, and some typos. In addition, it does not have its conclusion, so the readers have to make their own conclusions about the content and lessons learned from Ways to Improve the Young Generations Culture.

A cultured generation reflects a superior generation that embraces its own culture. As time goes by, lots of foreign cultures enter and gradually shift the Indonesian culture. This is the primary reason why the young generations are starting to abandon their culture. On the other hand, their inability to filter a good culture causes the young generations to get carried away by Western culture easily. Therefore, it is important to introduce Indonesian culture through art since childhood to increase their love for their culture. That way, they can be more selective in filtering what fits them well, and Indonesian culture can be preserved. Moreover, 
the world can appreciate Indonesian culture if this era of globalization can be appropriately utilized.

\section{REFERENCES}

1. Aidah SN. Langkah Membangkitkan Generasi Muda yang Berbudaya: Mengenal Budaya indonesia, Upaya Melestarikan Budaya Indonesia, Cara Gaul Millenial Berbudaya dan Peran Bahasa dalam Komunikasi Antar Budaya (Ways to Improve the Young Generations Culture: Get to Know Indonesian Culture, an Efforts to Preserve Indonesian Culture, How Millennial Getting Along, and the Role of Language in Intercultural Communication). First Edition. Bojonegoro: Penerbit KBM Indonesia; 2020. 71 p.

\section{Author's Biography}

Siti Nur Aidah is a talented young woman born in Tuban on December 29, 1997. She is often referred to by the name Aida. She grew up and spent her teenage years in Tuban as the last child out of three. Siti Nur Aidah completed her last education in 2020 at Institut Agama Islam Sunan Giri Bojonegoro. She majored in Madrasah Ibtidaiyah Teacher Education (Pendidikan Guru Madrasah Ibtidaiyah). Aida is fond of writing poetry. This hobby of hers started from the heartbreak she could not convey through words. Eventually, she decided to write poetry and books to represent her thoughts and feelings. She has written four poetry anthology books and 151 non-literary titles. The four poetry anthology books that she has written are Aku dan Pendidikan (as a result of writing with IMPI Pusat in 2019), Kisah yang Kusampaikan poetry (as a result of taking a poetry writing class in 2020), Sajak Sandiwara poetry (published with her friends from extracurricular club in 2020), Liku Tanpa Ujung poetry (as a result of taking a poetry writing class in 2020). Aida's poetry, besides being published in book form, was also uploaded to social media so the readers can understand what she wanted to convey in her poetry since it tends to be vague and meaningful. As of now, Aida is keeping herself busy by working at Penerbit KBM Indonesia. From publishing her book in Penerbit KBM Indonesia, she was eventually asked to become a script editor at KBM. 